\title{
Profil Burnout Study Mahasiswa dalam Pembelajaran Daring di Era New Normal
}

\author{
Ahmad Rifai ${ }^{1}$, Triyono ${ }^{2}$ \\ STKIP PGRI Sumatera Barat ${ }^{1}$ \\ Email: ahmadrifai291198@gmail.com \\ STKIP PGRI Sumatera Barat ${ }^{2}$ \\ Email: triyonompd@gmail.com
}

\begin{abstract}
ABSTRAK
Permasalahan ini penelitian ini dilator belakangi masih adanya mahasiswa yang kurang bersemangat, kurang puas berargumen dalam proses pembelajaran daring, rasa kecemasan yang tinggi, dan adanya rasa bosan mahasiswa selama proses pembelajaran daring. Tujuan dari penelitian ini adalah untuk mendeskripsikan: burnout study mahasiswa dalam pembelajaran daring di era new normal, dilihat dari aspek kelelahan emosi, kelelahan fisik, kelelahan kognitif, dan kehilangan motivasi. Penelitian ini dilakukan dengan menggunakan metode deskriptif kuantitatif. Populasi penelitian adalah 217 mahasiswa. Teknik pengambilan sampel dengan menggunakan proposional random sampling. Jumlah sampel dalam penelitian ini 141 orang responden. Instrumen yang digunakan angket. Analisis data dengan skor interval. Hasil penelitian ini mengungkapkan secara umum burnout study mahasiswa dalam pembelajaran daring di era new normal berada pada kategori rendah. Selanjutnya dilihat dari indikator: 1) ) Burnout study mahasiswa dalam pembelajaran daring di era new normal berdasarkan indikator kelelahan emosi berada pada kategori cukup tinggi, 2) Burnout study mahasiswa dalam pembelajaran daring di era new normal berdasarkan indikator kelelahan fisik berada pada kategori cukup tinggi, 3) Burnout study mahasiswa dalam pembelajaran daring di era new normal berdasarkan indikator kelelahan kognitif berada pada kategori rendah, 4) Burnout study mahasiswa dalam pembelajaran daring di era new normal berdasarkan indikator kehilangan motivasi berada pada kategori rendah. Berdasarkan temuan penelitian ini direkomendasikan kepada mahasiswa agar selalu meminimalisir dan menghilangkan burnout studynya dalam pembelajaran daring sehingga mampu mencapai kesuksesan dalam belajar.
\end{abstract}

Keywrod: Burnout Study, Pembelajaran Daring, Era New Normal 


\title{
Burnout Study Profile Of Internal Students Online Learning In The New Normal Era
}

\begin{abstract}
This research problem is motivated by the existence of students who are less enthusiastic, less satisfied in arguing in the online learning process, a high sense of anxiety, and the boredom of students during the online learning process. The purpose of this study is to describe: student burnout study in online learning in the new normal era, seen from the aspects of emotional exhaustion, physical exhaustion, cognitive fatigue, and loss of motivation. This research was conducted using a quantitative descriptive method. The research population was 217 students. The sampling technique used proportional random sampling. The number of samples in this study was 141 respondents. The instrument used is a questionnaire. Data analysis with interval scores. The results of this study reveal that in general, student burnout studies in online learning in the new normal era are in the low category. Furthermore, it can be seen from the indicators: 1) ) Burnout study of students in online learning in the new normal era based on indicators of emotional exhaustion is in the fairly high category, 2) Burnout study of students in online learning in the new normal era based on indicators of physical fatigue is in the fairly high category, 3) Burnout study of students in online learning in the new normal era based on indicators of cognitive fatigue is in the low category, 4) Burnout study of students in online learning in the new normal era based on indicators of loss of motivation is in the low category. Based on the findings of this study, it is recommended that students always minimize and eliminate burnout studies in online learning so that they can achieve success in learning.
\end{abstract}

Keywords: Burnouut Study, Online Learning, New Normal Era

\section{PENDAHULUAN}

Pandemi Covid-19 memberikan dampak yang sangat besar terhadap semua aspek kehidupan, termasuk dalam dunia pendidikan ditingkat pendidikan tinggi. Proses pembelajaran di pendidikan tinggi yang awalnya dilakukan secara langsung atau tatap muka sekarang dilakukan secara Online. Idealnya dengan diadakannya pembelajaran secara daring bisa menjadikan mahasiswa lebih mandiri dan siap terhadap perkembangan zaman atau revolusi industri 4.0. lebih lanjut sejalan dengan peraturan pemerintah yang di keluarkan oleh Kementrian Pendidikan dan Kebudayaan (Kemendikbud) bahwa dalam rangka pemenuhan hak peserta didik untuk mendapatkan layanan pendidikan selama darurat penyebaran Corona Virus 
Disease (Covid-19) melalui penyelenggaraan Belajar dari Rumah (daring). Dengan dilakukan pembelajaran daring maka kesiapan terhadap penggunaan teknologi harus ditingkatkan.

Semua negara terdampak telah berupaya membuat kebijakan terbaiknya dalam menjaga kelanggengan layanan pendidkan. Indonesia juga menghadapi beberapa tantangan nyata yang harus segera dicarikan solusinya antara lain : (1) ketimpangan teknologi antara sekolah di kota besar dan daerah, (2) keterbatasan kompetensi guru dalam pemanfaatan aplikasi pembelajaran, (3) keterbatasan sumberdaya untuk pemanfaatan teknologi Pendidikan seperti internet dan kuota, (4)relasi guru-muridorang tua dalam pembelajaran daring yang belum integral. Pemberlakuan kebijakan physical distancing yang kemudian menjadi dasar pelaksanaan belajar dari rumah, dengan pemanfaatan teknologi informasi yang berlaku secara tiba-tiba, tidak jarang membuat pendidik dan siswa kaget termasuk orang tua bahkan semua orang yang berada dalam rumah. Pembelajaran teknologi informasi memang sudah diberlakukan dalam beberapa tahun terakhir dalam sistem pendidikan di Indonesia. Namun, pembelajaran daring yang berlangsung sebagai kejutan dari pandemi Covid-19, membuat kaget hampir di semua lini, dari kabupaten/kota, provinsi, pusat bahkan dunia internasional.

Menurut Asmuni (2020:25) "sistem pembelajaran daring merupakan sistem pembelajaran tanpa tatap muka secara langsung antar guru dan peserta didik, melainkan secara online yang menggunakan jaringan internet". Pemerintah mengeluarkan kebijakan untuk belajar di rumah sehingga mahasiswa tidak hadir ke kampus dan mengalihkannya di rumah masing-masing. Dalam situasi ini, mahasiswa dituntut untuk membuat suasana belajar yang nyaman dan menyenangkan di rumah. Sampai saat ini, pemerintah telah mengambil langkah refresif seperti melakukan aturan pembatasan sosial atau Social Distancing. Hal inilah membuat dunia pendidikan kita menjadi berubah dari pembelajaran luring (tatap muka) menjadi pembelajaran daring (online). Karena satu satunya solusi yang bisa ditawarkan dengan melakukan pembelajaran daring (online learning/ online classroom). Hal ini seperti memberikan dampak positif bagi dosen dan 
mahasiswa untuk belajar secara daring. Indonesia menghadapi beberapa tantangan nyata yang harus segera dicarikan solusinya: (1) ketimpangan teknologi daerah, (2) keterbatasan kompetensi dosen dalam pemanfaatan aplikasi pembelajaran, (3) keterbatasan sumberdaya untuk pemanfaatan teknologi Pendidikan seperti internet dan kuota.

Pemberlakuan kebijakan physical distancing yang kemudian menjadi dasar pelaksanaan belajar dari rumah, dengan pemanfaatan teknologi informasi yang berlaku secara tiba-tiba, tidak jarang membuat dosen dan mahasiswa kaget termasuk orang tua bahkan semua orang yang berada dalam rumah. Pembelajaran teknologi informasi memang sudah diberlakukan dalam beberapa tahun terakhir dalam sistem pendidikan di Indonesia. Namun, pembelajaran daring yang berlangsung sebagai kejutan dari pandemi Covid-19, membuat kaget hampir di semua lini, dari kabupaten/kota, provinsi, pusat bahkan dunia internasional. Selain itu hal terpenting dalam proses Pembelajaran Daring adalah kesiapan dosen dalam mengelola pembelajaran daring dan kesiapan mahasiswa dalam mengikuti perubahan proses pembelajaran daring. Kesiapan dosen dalam mengelola pembelajaran secara daring sangat penting karena jika dosen bisa memberikan pembelajaran yang menyenangkan, humanis, metode yang bervariasi, serta penyiapan materi pembelajaran yang kontekstual sesuai dengan capaian pembelajaran diharapkan dalam mata kuliah yang diajarkan. Sehingga dengan pengelolaan yang bagus oleh dosen maka akan menjadikan mahasiswa termotivasi dalam mengikuti pembelajaran secara daring. Namun perlu ditekankan juga, mahasiswa juga harus siap dengan perubahan, bisa lebih mandiri dan bisa menciptakan proses pembelajaran menyenangkan sehingga terhindar dari Burnout akademik.

Selanjutnya Farber (1991:7) menegaskan keacuhan teman, ketidak pedulian orang tua, kurangnya apresiasi masyarakat terhadap citra pelajar, ruang belajar yang terlalu padat, beban tugas yang berlebihan, bangunan fisik sekolah yang tidak baik, hilangnya otonomi dan keuanganyang tidak memadai merupakan beberapa faktor yang tepat membuat individu mengalami kejenuhan belajar. Selanjutnya Muchinsky (1987:19) menyatakan bahawa Burnout merupakan suatu reaksi antara person- 
environment yang realatif baru, yang dikenali oleh para psikolog dibidang industri dan organisasi. Dikatakan bahwa Burnout merupakan sindrom kelelahan emosional dan sisnisme yang muncul diantara orang-orang yang bekerja pada "poeole work"misalnya: guru, perawat, pekerja sosial, dan konselor. Muchinsky menjelaskan lebih jauh, di dalam suatu organisasi terdapat dua kekuatan yang berpengaruh di tempat kerja, satu kekuatan berasal dari individu, dan yang lain berasal dari organisasi.

Demereuti, dkk (2002:428) Burnout adalah sindrom dari pengalaman negatif dalam bekerja, termasuk rasa kelelahan dan terlepas dari pekerjaan. Kelelahan didefinisikan sebagai konsekuensi dari aktivitas fisik, emosi, dan ketegangan kognitif yang berkepanjangan, sebagai hasil dari suatu pekerjaan tertentu (stressor) yang berkepanjangan.Suwarjo \& Purnama (2014:12) mengartikan Burnout sebagai suatu keadaan keletihan (exhaustion) fisik, emosional dan mental dimana cirinya sering disebut physical depletion, yaitu dicirikan dengan perasaan tidak berdaya dan putus harapan, keringnya perasaan gagal untuk mencapai tujuan diri yang ideal. Schaufeli dan Buunk (1996:98) menjelaskan bahwa burnout hanya dapat dialami oleh individu yang memiliki antusias, memiliki tujuan dan harapan yang tinggi terhadap pekerjaannya. Pada awal bekerja, umumnya perawat lansia yang mengalami burnout termaksud individu yang bersemangat, energik, optimis, memiliki prinsip yang kuat dan mau bekerja keras untuk meraih prestasi serta tidak mengenal istilah gagal (Zulkarnain, 2011). Akan tetapi, adanya ketidakseimbangan antara kebutuhan dan sumber daya yang dimiliki dalam waktu yang lama dan banyak tekanan berkepanjangan selama bekerja mengakibatkan individu mengalami burnout (Brill dalam Schaufeli dan Buunk, 1996).

Senada dengan pendapat Schaufeli et al. (200:465) mendefinisikan "Burn out among students refers to feeling exhausted because of study demands, having a cynical and detached attude toward one's study, and feeling incompetent as a student". Secara umum, kejenuhan belajar yang dirasakan mahasiswa tercermin dalam bentuk perilaku seperti malas, mudah putus asa, acuh tak acuh, menunjukkan sikap pemurung, mudah tersinggung bahkan tak jarang bersikap menyimpang 
seperti membolos, melalaikan tugas untuk belajar. New normal merupakan sebuah istilah yang digunakan untuk menggambarkan kondisi yang berbeda dengan kondisi sebelumnya yang pada akhirnya akan menjadi suatu hal lumrah yang baru. New normal hadir untuk memastikan respons berbagai aspek dalam masyarakat yang dimulai dari makro, meso, dan mikro dan efisiensi adaptasi terhadap perubahan yang terjadi. Hal ini akan memastikan kesiapan masyarakat dalam membangun kembali apa yang telah dibuat oleh suatu krisis maupun pandemi dengan kondisi yang lebih kuat (Buheji \& Ahmed, 2020).

Peneliti melakukan observasi pada tanggal 12 April 2021 peneliti menemukan mahasiswa STKIP PGRI Sumatera Barat bahwa masih adanya mahasiswa yang memiliki burnout (kejenuhan) dalam pembelajaran daring di era new normal. Masalah yang ditemukan diantaranya adanya mahasiswa yang merasa kehilangan rasa semangat setelah melakukan pembelajaran daring, sakit kepala setelah melakukan pembelajaran daring, merasa bosan dalam pembelajaran daring, kurang memahami pembelajaran saat proses pembelajaran, dan kurang puas berargumen dalam proses pembelajaran daring.

Peneliti juga melakukan tanya jawab melalui media komunikasi pada 13 April 2021 terhadap mahasiswa yang diteliti dari BP/Angkatan 2018-2020, penelitian ini dilakukan pada beberapa orang mahasiswa dari setiap angkatan mulai dari angkatan 2018 sampai 2020. Dari hasil wawancara peneliti mendapatkan informasi bahwa masih adanya mahasiswa yang kurang bersemangat, kurang puas berargumen dalam proses pembelajaran daring, rasa kecemasan yang tinggi, dan adanya rasa bosan mahasiswa selama proses pembelajaran daring. Berdasarkan fenomena diatas maka penulis tertarik untuk melakukan sebuah penelitian tentang "Profil Burnout Study Mahasiswa Dalam Pembelajaran Daring di Era New Normal (Studi Pada Mahasiswa BK STKIP PGRI Sumatera Barat)”.

\section{METODE PENELITIAN}

Berdasarkan batasan masalah dan tujuan penelitian yang dirumuskan, maka penelitian ini berjenis penelitian deskriptif kuantitatif. Iskandar (2009: 17) 
mengemukakan bahwa penelitian kuantitatif merupakan penelitian yang dilakukan untuk mendapatkan jawaban dari permasalahan atau gambaran umum tentang suatu fenomena atau gejala yang dilandasi pada teori, asumsi atau andaian. Dalam hal ini dapat diartikan sebagai pola pikir yang menunjukkan hubungan antara variabelvariabel yang akan diteliti, sekaligus mencerminkan jenis dan jumlah rumusan masalah yang perlu dijawab melalui penelitian, teori yang digunakan adalah untuk merumuskan hipotesis, dan teknik analisis statistik yang hendak digunakan.

\section{HASIL DAN PEMBAHASAN}

Berdasarkan hasil penelitian dapat diungkapkan profil burnout study mahasiswa dalam pembelajaran daring di era new normal studi pada mahasiswa BK STKIP PGRI Sumatera Barat berada pada kategori rendah. Selanjutnya berdasarkan data yang dikumpulkan mengenai profil burnout study mahasiswa dalam pembelajaran daring di era new normal studi pada mahasiswa BK STKIP PGRI Sumatera Barat dilihat dari indikator kehilangan motivasi tergolong kedalam kategori rendah.

\section{a. Burnout Study Berdasarkan Kelelahan Emosi}

Berdasarkan pengolahan data dapat diketahui burnout study dalam pembelajaran berdasarkan kelelahan emosi berada pada kategori sangat tinggi dengan frekuensi 12 orang dengan persentase 8,57\%. Pada kategori tinggi dengan frekuensi 20 orang dengan persentase 14,29\%. Pada kategori cukup tinggi dengan frekuensi 46 orang dengan persentase 32,86\%. Pada kategori rendah dengan frekuensi 38 orang dengan persentase 27,14\%. Sedangkan pada kategori sangat rendah dengan frekuensi 24 orang dengan persentase 17,14\%. Berdasarkan pada tingkat kelelahan emosi ini tingkat kejenuhan belajar mahasiswa di dalam pembelajaran daring ini di kategorikan cukup tinggi. Hal yang membuat mahasiswa cukup tinggi kejenuhan dalam belajarnya yaitu adanya terkendala di dalam pembelajaran berlangsung, seperti habisnya data internet mahasiswa saat belajar, terkendala dengan jaringan, dan juga habisnya batrai Hendphone atau juga batrai leptop mahasiswa saat menggunakan google form atau juga google meet tersebut. 
Menurut Maslach dan Jackson (1981:99) menyatakan bahwa kelelahan emosional adalah suatu perasaan emosional yang berlebihan dan sumber daya emosional seseorang yang telah habis yang dialirkan oleh kontak seseorang dengan individu lain. Hal ini menunjukan bahwa kelelahan emosi muncul diakibatkan oleh adanya kontak dengan orang lain yang menguras sumber daya emosinya. Berdasarkan definisi kelelahan yang telah dijelaskan sebelumnya, maka kelelahan emosi ini merupakan keadaan penurunan sumberdaya emosi yang dialirkan karena kontak dengan individu lain. Kelelahan yang berhubungan dengan perasaan dari diri yang dicirikan seperti sinisme dan mudah tersinggung pada orang lain, mudah marah, dan mudah sedih, merasa gelisah, tertekan dan tidak berdaya selain itu mudah merasa bosan. Berdasarkan pendapat diatas dapat disimpulkan bahwa kelelahan emosi (emotional exhaustion) merupakan kondisi yang melemahnya perasaan pribadi individu dan sumber-sumber emosinya menjadi terkuras. Kondisi ini diakibatkan oleh adanya kontak individu dengan individu lain yang menguras sumberdaya emosinya.

\section{b. Burnout Study Berdasarkan Kelelahan Fisik}

Berdasarkan hasil pengolahan data dapat diketahui burnout study dalam pembelajaran berdasarkan kelelahan fisik berada pada kategori sangat tinggi dengan frekuensi 6 orang dengan persentase 4,29\%. Pada kategori tinggi dengan frekuensi 17 orang dengan persentase $12,14 \%$. Pada kategori cukup tinggi dengan frekuensi 34 orang dengan persentase 24,29\%. Pada kategori rendah dengan frekuensi 45 orang dengan persentase $32,14 \%$. Sedangkan pada kategori sangat rendah dengan frekuensi 38 orang dengan persentase 27,14\%. Berdasarkan pada tingkat kelelahan fisik ini tingkat kejenuhan belajar mahasiswa di dalam pembelajaran daring ini di kategorikan sangat rendah. Hal yang membuat mahasiswa sangat rendah kejenuhan dalam belajarnya dikarenakan sedikitnya mahasiswa yang mengalami gangguan dengan fisiknya saat belajar, seperti gangguan otot, nyeri sendi, pegal-pegal, sakit kepala, dan lain-lain. Selanjutnya mahasiswa juga dapat mengatasi kelelahan 
fisiknya dengan melekukan istirahat sejenak, agar dapat membugarkan keadaan fisik nya lagi.

Menurut Ikhram, 2012 (Rahman 2012:74). Kelelahan fisik adalah kelelahan yang ditandai dengan adanya keletihan, kejenuhan, ketegangan otot dan munculnya perilaku yang baru. Kelelahan fisik adalah kelelahan yang disebabkan oleh kerja jasmani sedangkan kelelahan psikis adalah perasaan tertekan,cemas,dan tegang yang dialami oleh individu karena pengaruh dari situasi dan kondisi lingkungan sekitarnya. Kelelahan ini bersifat fisik dan energi fisik. Pada kelelahan fisik ditandai sakit pada bagian tubuh seperti sakit punggung, tegang pada otot leher dan bahu, rasa ngilu dan letih yang parah, sakit kepala, sering demam dan flu, susah tidur dan perubahan pola makan. Sedangkan untuk kelelahan energi fisik ditandai oleh penurunan energi menjadi rendah dan adanya kelelahan secara terus menerus hingga tenggelamnya energi tersebut.

Berdasarkan pendapat di atas dapat disimpulkan bahwa kelelahan fisik disebabkan oleh kelemahan pada otot. Suplai darah yang mencukupi dan aliran darah ke otot sangat penting, dikarenakan menentukan kemampuan metabolisme dan memungkinkan kontraksi otot tetap berjalan. Kontraksi otot yang kuat mengakibatkan tekanan pada otot dan dapat menghentikan aliran darah. Sehingga kontraksi maksimal hanya dapat berlangsung beberapa detik. Gangguan pada aliran darah dapat menyebabkan kelelahan otot yang berakibat otot tidak dapat berkontraksi, meskipun rangsangan syaraf motorik masih berjalan.

\section{c. Burnout Study Berdasarkan Kognitif}

Berdasarkan hasil pengolahan data dapat diketahui burnout study dalam pembelajaran berdasarkan kelelahan kognitif berada pada kategori sangat tinggi dengan frekuensi 7 orang dengan persentase 5,00\%. Pada kategori tinggi dengan frekuensi 16 orang dengan persentase 11,43\%. Pada kategori cukup tinggi dengan frekuensi 43 orang dengan persentase 30,71\%. Pada kategori rendah dengan frekuensi 42 orang dengan persentase 30,00\%. Sedangkan pada kategori sangat rendah dengan frekuensi 32 orang dengan persentase 22,86\%. Berdasarkan pada 
tingkat kelelahan fisik ini kejenuhan belajar mahasiswa di dalam pembelajaran daring ini di kategorikan cukup tinggi. Hal yang membuat mahasiswa cukup tinggi kejenuhan dalam belajarnya yaitu dapat membuat mahasiswa berfikir dan dapat membuat mahasiswa frustasi dalam keadaan tersebut, seperti terlalu banyak berfikir dan juga terlalu lebih mementingkan pekerjaan di bandingkan dengan kesehatan dirinya. Jadi dengan itulah tingkat kelelehan fisik dikategorikan cukup tinggi dengan kejenuhan belajarnya.

Menurut Schaufeli \& Bruunk (1996: 324) kelelahan kognitif ini siswa yang sedang mengalami kejenuhan cenderung sedang mendapat beban yang terlalu berat pada otak. Hal ini kemudian berdampak seperti yang diungkapkan kahlil yakni ketidakmampuan untuk berkonsentrasi, mudah lupa, dan kesulitan dalam membuat keputusan. Berdasarkan uraian di atas dapat disimpulkan bahwa Kelelahan kognitif merupakan kelelahan mental yang terjadi ketika seseorang harus bekerja dengan pikiran untuk waktu yang lama.

\section{d. Burnout Study Berdasarkan Kehilangan Motivasi}

Berdasarkan hasil pengolahan data dapat diketahui burnout study dalam pembelajaran berdasarkan kehilangan motivasi berada pada kategori sangat tinggi dengan frekuensi 3 orang dengan persentase 2,14\%. Pada kategori tinggi dengan frekuensi 13 orang dengan persentase 9,29\%. Pada kategori cukup tinggi dengan frekuensi 34 orang dengan persentase 24,29\%. Pada kategori rendah dengan frekuensi 59 orang dengan persentase 42,14\%. Sedangkan pada kategori sangat rendah dengan frekuensi 31 orang dengan persentase 22,14\%. Berdasarkan pada tingkat kehilangan motivasi ini tingkat kejenuhan belajar mahasiswa di dalam pembelajaran daring ini di kategorikan rendah. Hal yang membuat mahasiswa rendah kejenuhan dalam belajarnya yaitu hilangnya motivasi mahasiswa di dalam belajar, seperti tidak adanya keseriusan mahasiswa di dalam belajar, tidak efektif dalam belajar, jadi dengan itu membuat mahasiswa kehilangan motivasi belajarnya dan tidak adanya dukungan semangat dari teman-teman saat belajar lagi. 
Menurut Bahrer-Kohler (2012: 57) bahwa kehilangan motivasi pada siswa ditandai dengan hilangnya idealisme, siswa sadar dari impian mereka yang tidak realistis, dan kehilangan semangat. Dari gejala di atas maka siswa sudah dianggap kehilangan motivasi. Bentuk lain dari kehilangan motivasi adalah penarikan diri secara psikologis sebagai respon dari stres yang berlebihan dan rasa ketidakpuasan.

\section{KESIMPULAN}

Berdasarkan analisis data dan pembahasan dapat diambil kesimpulaan mengenai profil burnout Study mahasiswa dalam pembelajaran daring di era new normal studi pada mahasiswa BK STKIP PGRI Sumatera Barat. Temuan peneliti ini dapat disimpulkan sebagai berikut.

1. Profil burnout study mahasiswa dalam pembelajaran daring di era new normal (studi pada mahasiswa BK STKIP PGRI Sumatera Barat) berdasarkan indikator kelelahan emosi berada pada kategori cukup tinggi. Artinya mahasiswa mengalami kelelahan emosi yang cukup tinggi saat pembelajaran daring berlangsung.

2. Profil burnout study mahasiswa dalam pembelajaran daring di era new normal (studi pada mahasiswa BK STKIP PGRI Sumatera Barat) berdasarkan indikator kelelahan fisik berada pada kategori cukup tinggi. Artinya mahasiswa mengalami kelelahan fisik yang rendah saat pembelajaran daring berlangsung.

3. Profil burnout study mahasiswa dalam pembelajaran daring di era new normal (studi pada mahasiswa BK STKIP PGRI Sumatera Barat) berdasarkan indikator kelelahan kognitif berada pada kategori rendah. Artinya mahasiswa mengalami kelelahan kognitif yang cukup tinggi saat pembelajaran daring berlangsung.

4. Profil burnout study mahasiswa dalam pembelajaran daring di era new normal (studi pada mahasiswa BK STKIP PGRI Sumatera Barat) berdasarkan indikator kehilangan motivasi berada pada kategori rendah. Artinya mahasiswa mengalami kelelahan kognitif yang rendah saat pembelajaran daring berlangsung. 


\section{DAFTAR PUSTAKA}

Bahrer-Kohler, S. 2012. Burnout for Expert: Prevention in the context of living and working. London: Springer Science \& Business Media.

Buheji, M, \& Ahmed, D. 2020. Planning Competency In the New NormalEmployability Competency in Post-COVID-19 Pandemic, Business Management: and Strategy, 160-179

Farber, B.A. (1991). Crisis and Education: Stress and Burnout in the American Teacher. San Fransisco: Jossey Bass

Iskandar. 2009. Metodologi Penelitian Pendidikan dan Sosial (Kualitatif dan Kuantitaf). Jakarta: GP Press.

Muchinsky, P.M. 1987. Psychology Applied to Work. 2ed. The Dorsey Press. Chicago llli-nois

Rahman, Adi. 2012. Keefektifan Pembelajaran dengan Pendekatan Pendidikan Matematika Realistik Indonesia Ditinjau dari Pencapaian Kemampuan Pemecahan Masalah Matematika Dan Karakter Peserta Didik SMP. Skrpsi. FMIPA. UNY

Schaufeli, W., \& Enzmann, D. 1998. The burnout Companion to Study and Practice: A critical analysis. CRC press. 